
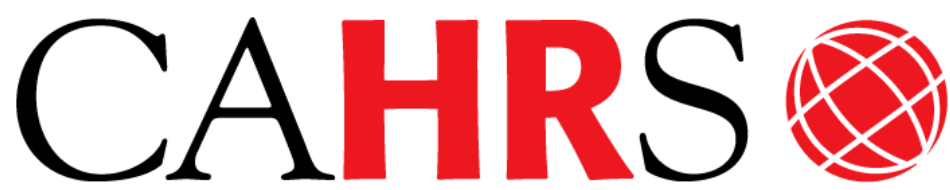

Center for Advanced Human Resource Studies Uorhing Prper 马erieg
CAHRS / Cornell University 187 Ives Hall

Ithaca, NY 14853-3901 USA

Tel. 607 255-9358

www.ilr.cornell.edu/CAHRS/

\title{
Global Human Resource Metrics
}

\author{
Helen De Cieri \\ John W. Boudreau
}

Working Paper 03 - 07

CORNELL illrschool of Industrial and Labor Relations 


\title{
Global Human Resource Metrics
}

\author{
Helen De Cieri \\ Department of Management \\ Monash University \\ P.O. Box 197 \\ Caulfield East \\ Victoria AUSTRALIA 3145 \\ Tel. (+613) 9903.2013 \\ Fax: (+613) 9903.2718 \\ helen.decieri@buseco.monash.edu.au \\ John W. Boudreau \\ Center for Advanced Human Resource Studies \\ Cornell University \\ 393 Ives Hall \\ Ithaca, New York 14853-3901 \\ (607) 255-7785 \\ jwb6@cornell.edu
}

March, 2003

http://www.ilr.cornell.edu/cahrs

This paper has not undergone formal review or approval of the faculty of the ILR School. It is intended to make results of Center research available to others interested in preliminary form to encourage discussion and suggestions. 


\section{Global Human Resource Metrics}

\section{Introduction}

What is the logic underlying global human resources (HR) measurement in your organization? In your organization, do you measure the contribution of global HR programs to organizational performance? Do you know what is the most competitive employee mix, e.g., proportion of expatriates vs. local employees, for your business units? (How) do you measure the cost and value of the different types of international work performed by your employees?

In the globalized economy, organizations increasingly derive value from human resources, or "talent" as we shall also use the term here (Boudreau, Ramstad \& Dowling, in press). The strategic importance of the workforce makes decisions about talent critical to organizational success. Informed decisions about talent require a strategic approach to measurement. However, measures alone are not sufficient, for measures without logic can create information overload, and decision quality rests in substantial part on the quality of measurements. An important element of enhanced global competitiveness is a measurement model for talent that articulates the connections between people and success, as well as the context and boundary conditions that affect those connections.

This chapter will propose a framework within which existing and potential global HR measures can be organized and understood. The framework reflects the premise that measures exist to support and enhance decisions, and that strategic decisions require a logical connection between decisions about resources, such as talent, and the key organizational outcomes affected by those decisions. Such a framework may provide a useful mental model for both designers and users of HR measures.

We will illustrate how this framework can be applied by using a range of practical measurement examples. While our analysis is supported by examples of practical applications drawn from survey reports and interviews with key managers in several multinational companies, our key sources are: 
- Cargill, Incorporated, an international marketer, processor and distributor of agricultural, food, financial and industrial products and services with 97,000 employees in 59 countries.

- Global Relocation Trends 2001 Survey Report (2002) sponsored by GMAC Global Relocation Services, National Foreign Trade Council (NFTC), and SHRM Global Forum. Respondents to this survey were $150 \mathrm{HR}$ executives, $83 \%$ of whom were employed in multinational enterprises with U.S. headquarters.

\section{Talentship: A Decision Science for HR}

HR metrics are often evaluated by asking clients and key decision makers for their opinions about measures. This is in stark contrast to the approach taken in fields such as finance, where the focus is on the key organizational outcomes of the measures. This is not to argue against the possible use of subjective judgments, attitudes, and even non-quantitative measures in HR. We acknowledge that more mature and organizationally powerful decision sciences such as finance, marketing and operations management rely on some "soft" measures, and that they are not immune from subjectivity and alternative interpretations. However, it is important that the field of HR avoid accepting virtually any measurement method, criterion and stakeholder perspective that someone feels might be useful. To do so would create measurement systems with less credibility and value. Rather, we are suggesting that HR measurement strive to reflect a deep and logical connection between talent and key organizational outcomes, just as finance does for monetary resources and marketing does for customer resources.

Recognizing that a significant future challenge for global organizations will be to develop and enhance their ability to link talent to global strategic success, Boudreau et al. (in press) have proposed that it is necessary to fully develop a decision science for global talent. This requires models that are logical, rich, and relevant for understanding talent. The complexity in the people-side of decision-making is due in part to the absence of a model for organizing measurement. The field of HR management needs to develop a decision science or model to 
support decisions about people. Boudreau and Ramstad (see 2002a, b) coined the term "talentship" to refer to this emerging decision science, capturing the distinction between the decision science of talent, and the professional practice of HR management. Talentship is to $\mathrm{HR}$ as finance is to accounting and as marketing is to sales. Talentship is the decision science that improves organizational performance by enhancing decisions that affect or depend on people. Talentship builds on HR management practices and measures, and goes further, to create a framework of tools that enhances decisions. These decisions may cover a broad range of areas, such as individual choices about whether to take an international assignment as a development opportunity, or global HR policies about decisions for international career development (Boudreau \& Ramstad, 2002a; Boudreau et al., in press).

It is well-recognized by academics and practitioners in the accounting and management fields that in the new economy, traditional corporate measurement systems must include measurement of intangible assets (Boudreau \& Ramstad, 2002a). In the field of strategic HR management, scholars (e.g., Boudreau, 1998; Boudreau \& Ramstad, 2002a) have noted the importance of understanding the value of talent. We propose here that such logic is essential to understanding, building and using global HR measurements.

HR professionals need to adopt a framework for metrics of human performance that will enable effective decisions to be made regarding people and success in organizations. Boudreau and Ramstad (2002a) viewed this as essential for the success of any HR measurement system. Measurement of global HR should enable the HR function to create and manage HR interventions to achieve outcomes for the organization, customers and employees. Further, the HR interventions need to be evaluated by objective metrics. Such a transformative process is a necessary element for elevating the HR function to an equal footing with other functional areas of the multinational enterprise ${ }^{1}$ (MNE) and develops the long-term support within the organization for HR policies and practices that are evidence-based and scientifically evaluated (Boudreau \& Ramstad, 1997; Murphy \& Zandvakili, 2000). 


\section{A Strategic Approach to the Measurement of Global HR}

MNEs face many complex HR issues and sometimes conflicting pressures for global integration and local differentiation (Schuler, Dowling \& De Cieri, 1993). For MNEs, there are specific and unique challenges related to the development of talent, as part of a strategic approach to HR. Achieving a balance between global co-ordination (integration) and local responsiveness (differentiation) is important. This balance may vary depending on the strategic context, resources and processes, and pivotal talent that are relevant in a particular situation (Boudreau et al., in press).

Global HR typically includes all HR programs conducted in MNEs across national borders. These may include global shared services, worldwide training programs, expatriation programs, and so on. Research and practice in global HR has largely focused on the management of expatriation, although there is increasing recognition of the need for strategic decision-making about global HR (see Dowling, Welch \& Schuler, 1999). Global HR management requires a flexible measurement framework to fit a great variety of situations, because managing across national boundaries requires attention to and measurement of additional context and boundary conditions.

The involvement of HR managers in strategic decision-making is important. However, research in MNEs has noted that leaders of non-HR functions may be reluctant to include the global HR function in strategic decisions, arguing that HR specialists often complicated decision-making (Stroh \& Caligiuri, 1998). Although making decisions relating to people is more difficult and complex, this aspect of decision-making is critical and it is likely to affect not only HR policies and practices but overall organizational performance as well. We argue that there is an imperative for global leaders to rigorously incorporate talent into their strategic planning and decisions. For HR to contribute to that process requires sophisticated measures that are clearly and logically linked to the key competitive concerns of strategic leaders, business managers and key constituents.

Three key challenges are important for the measurement of global HR programs: 
- Global-local balance. MNE management must focus simultaneously on global performance (the whole of the MNE) and subsidiary or regional performance (the parts). MNEs require generic measures that make sense across global operations, complemented by specific measures able to detect subtle differences among locations.

- Comparability of data. Performance evaluation data obtained from one subsidiary/region may not be comparable with that obtained from another due to local differences. It is important to decide which data are comparable and which are unique.

- Geographic dispersion. Separation by time and distance complicates judgments about the degree of fit between subsidiary performance and the long-term strategy of the MNE. With regard to global HR, distance may hamper connections between HR programs and organizational performance or even prevent such connections from being made. MNEs require measures that are not only financial; a balance between long- and short-term orientation, rather than a short-term focus on profits, may be required.

\section{A Model for Global HR Metrics}

A well thought-out framework for measurement acts as both a guide and a benchmark for evaluating the contribution of the organization's talent to strategy implementation (Becker, Huselid, \& Ulrich, 2001; Stroh \& Caligiuri, 1998) and provides a valid and systematic justification for resource allocation decisions. We advocate a strategic mental model that provides an actionable logic (Boudreau, Dunford, \& Ramstad, 2000) to analyze relationships between talent and the global context for MNEs, as shown in Figure 1. Our framework identifies the links between the external and organizational (i.e., internal) context for MNEs, the central linking elements related to talent, and MNE concerns and goals. This model should enhance our ability to address questions such as: Which HR approach is most appropriate to deal with the dynamic and volatile industry, as well as national and regional contexts encountered by MNEs? Which HR approach is most appropriate to optimize the strategic circumstances of MNEs? In posing such questions, we are mindful that it is inappropriate to simplify the nature of 
HR investments and suggest that there exists a single optimal HR architecture for managing all employees worldwide. Instead, HR investment will vary according to different business needs and subsidiaries may have a variety of different strategies within the parent company (Lepak \& Snell, 1999). This is precisely the reason why a general template should be more useful than any single measurement approach. Given the complexity and diversity of issues in global HR, there is a need for an approach to measurement that provides a useful generic framework, but one that can be customized to reflect the particular measurement and business logic of the appropriate business unit, industry, or regional context.

\section{Figure 1}

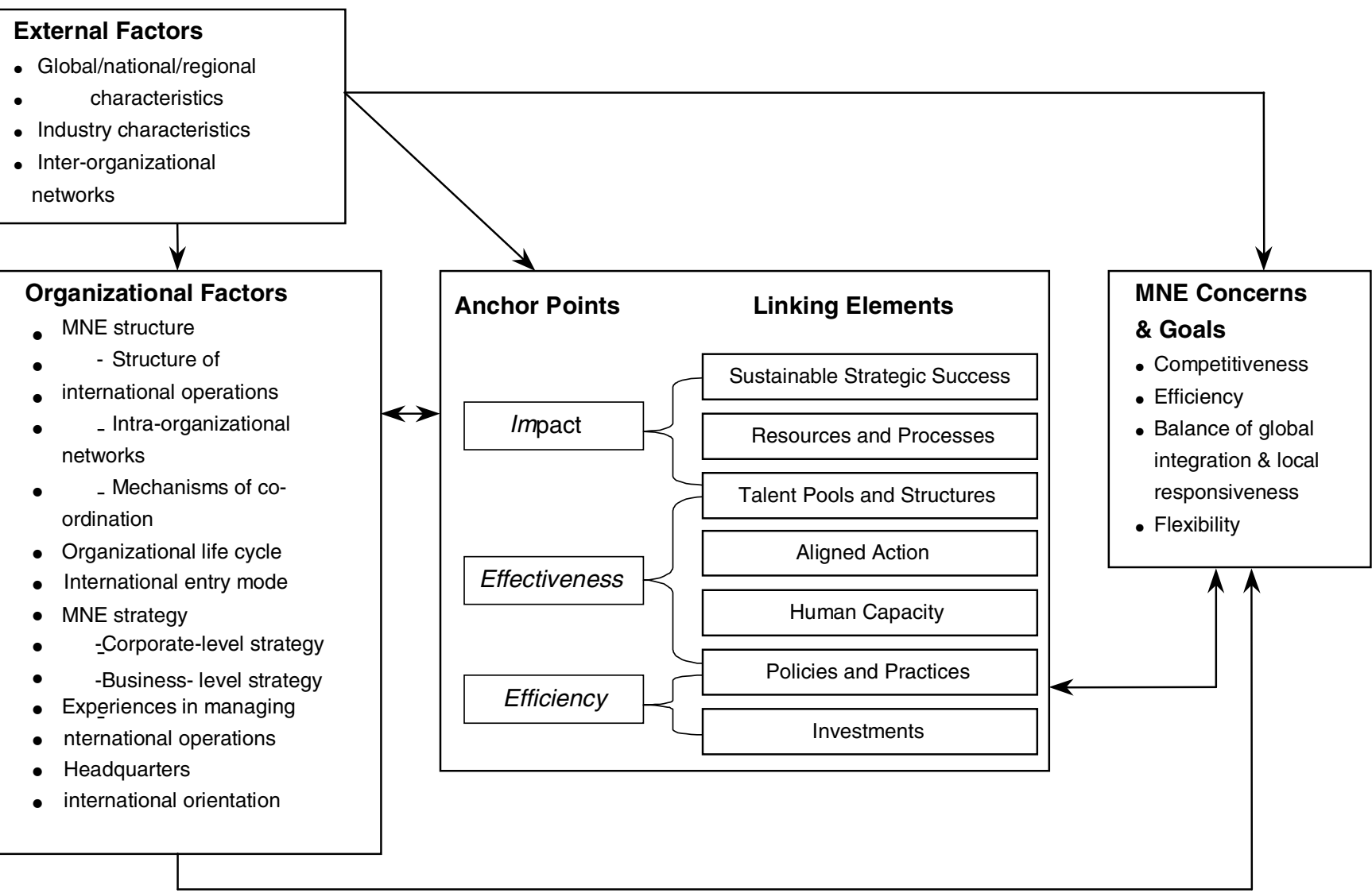

Figure 1. Global HR Model, incorporating the HC Bridge TM Model (Adapted from Boudreau, J.W. 2000. Global Strategic Success through Human Capital Value, CAHRS, Cornell University, NY) 
Our framework as shown in Figure 1 integrates two models: the Strategic HR in MNEs model (De Cieri \& Dowling, 1999) and the HC BRidge ${ }^{\mathrm{TM}}$ Model $^{2}$ (Boudreau \& Ramstad, 2002a). Figure 1 shows the linking elements of the $\mathrm{HC}$ BRidge ${ }^{\mathrm{TM}}$ Model combined with the contextual elements of strategic HR in MNEs. The resulting framework shows the external and organizational (i.e., internal) factors that impact on talent in MNEs, as well as the oftenconflicting pressures for global coordination (integration) and local responsiveness (differentiation). Identifying the links to MNE concerns and goals, or execution, is often a challenging task for strategic HR, but nonetheless important. It is important to acknowledge that our model provides a somewhat simplified representation of the dynamic inter-relationships between the elements shown in these various boxes. For example, 'industry characteristics' (an external factor) also are a core aspect of sustainable strategic success (a linking element). Similarly, 'inter-organizational networks' and 'MNE structure' (organizational factors) may be viewed as global versions of the linking element 'talent pools and structures'.

The logic underlying our framework should help global HR managers to identify enhanced measurement opportunities or synergies across the various boxes shown in the framework. With this logic, MNEs should be able to identify gaps in their measurement approaches, and develop a systematic approach that enables strategic connections to be made. In several of the MNEs investigated for this chapter, various elements of global HR are measured, but in a piecemeal or unconnected way. For example, a vast array of measures may be used to determine the efficiency of expatriation, yet the MNE may lack the measures, or the connections, for other elements, such as intra-organizational networks, or aligned actions.

To support and elaborate on the decision model of Figure 1, Table 1 provides a list of illustrative metrics that may be utilized for global HR. In the following sections, we outline the elements of this model and describe how this model can be applied, using the metrics shown in Table 1. Our aim is to provide examples that will assist organizations and HR professionals to understand the challenges facing global $\mathrm{HR}$, and to develop knowledge of the analytical tools that may be used. 
Table 1

Illustrative Measures of Global HR

\begin{tabular}{|c|c|}
\hline Elements of Global HR & Illustrative Measures \\
\hline \multicolumn{2}{|l|}{ External Factors } \\
\hline $\begin{array}{ll}\text { - } & \text { Global/national/regional characteristics } \\
\text { - } & \text { Political } \\
\text { - } & \text { Social } \\
\text { - } & \text { Economic } \\
\text { - } & \text { Technological } \\
\text { - } & \text { Legal } \\
\text { - } & \text { Environmental }\end{array}$ & $\begin{array}{l}\text { Benchmark survey, statistical databases, intelligence reports, legislation for: } \\
\text { - } \quad \text { government instability } \\
\text { - } \quad \text { inflation, recession } \\
\text { - } \quad \text { internet capabilities } \\
\text { - } \quad \text { equal opportunity legislation } \\
\text { - } \quad \text { environmental hazards }\end{array}$ \\
\hline $\begin{array}{ll} & \text { Industry characteristics } \\
\text { - } & \text { Industry size } \\
\text { - } & \text { Industry life cycle stage } \\
\text { - } & \text { Factors influencing profitability } \\
\text { - } & \text { Changing players in the market (e.g., new } \\
& \text { entrants) }\end{array}$ & $\begin{array}{ll}- & \text { Number of competitors } \\
- & \text { Size (sales) of competitors } \\
\text { - } & \text { Market maturity } \\
\text { - } & \text { Projections of market growth or decline } \\
\text { - } & \text { Relative pricing power and margins } \\
\text { - } & \text { Financial capital migration } \\
\end{array}$ \\
\hline $\begin{array}{ll}\text { - } & \text { Inter-organizational networks } \\
\text { - } & \text { Network relationships } \\
\text { - } & \text { Human and social capital }\end{array}$ & $\begin{array}{ll}- & \text { Extent of trust between network members } \\
\text { - } & \text { Quality, type and quantity of network relationships } \\
\text { - } & \text { Importance of the network to each partner organization } \\
\text { - } & \text { Extent of communication and knowledge sharing between network members }\end{array}$ \\
\hline \multicolumn{2}{|l|}{ Organizational Factors } \\
\hline $\begin{array}{ll}\text { - } & \text { MNE structure } \\
\text { - } & \text { Structure of international operations } \\
\text { - } & \text { Intra-organizational networks } \\
\text { - } & \text { Mechanisms of coordination }\end{array}$ & $\begin{array}{ll}\text { - } & \text { Extent of inefficiency and duplication across business units } \\
\text { - } & \text { Extent of inter-dependence amongst business units } \\
\text { - } & \text { Extent of business units' reliance on headquarters } \\
\text { - } & \text { Trust, quality, type and quantity of relationships between organizational units } \\
\text { - } & \text { Extent of communication and knowledge sharing between network members } \\
\text { - } & \text { Extent of bureaucratic vs. cultural controls }\end{array}$ \\
\hline - Organizational life cycle stage & $\begin{array}{l}\text { - } \quad \text { Age of organization } \\
\text { - } \quad \text { Age of products }\end{array}$ \\
\hline - International entry mode & $\begin{array}{ll}\text { - } & \text { Extent of control in joint ventures } \\
\text { - } & \text { Percentage of firm ownership in joint ventures } \\
\text { - } & \text { Percent of joint venture managers who are expatriates } \\
\text { - } & \text { Number of local vs. expatriate employees } \\
\end{array}$ \\
\hline $\begin{array}{ll}- & \text { MNE strategy } \\
- & \text { Corporate-level strategy } \\
\text { - } & \text { Business-level strategy }\end{array}$ & 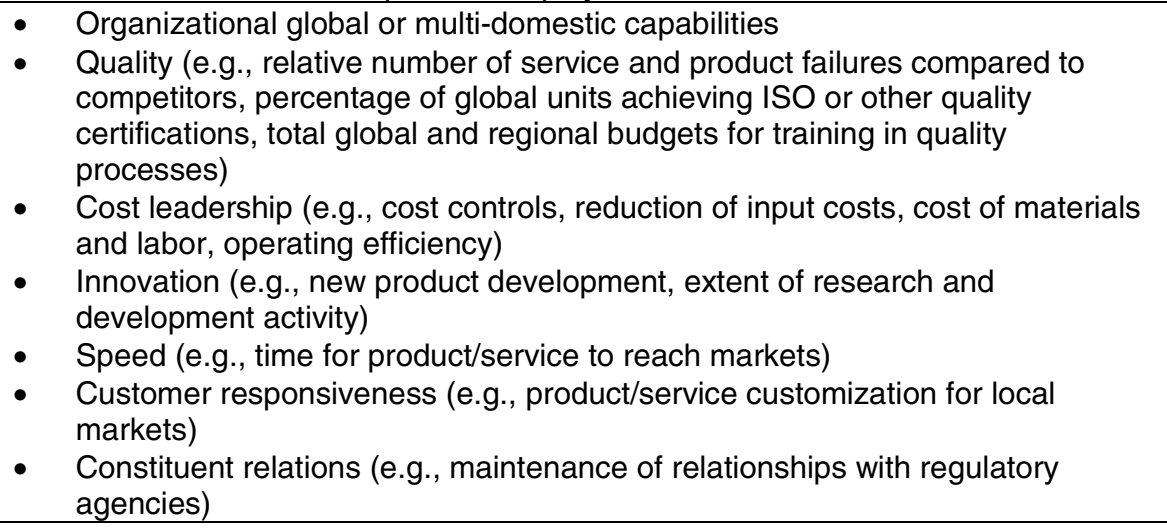 \\
\hline $\begin{array}{l}\text { - Experience in managing international } \\
\text { operations }\end{array}$ & $\begin{array}{l}\text { - } \quad \text { MNE experience in international business (e.g., years of operation by region or } \\
\text { country, the historical proportion of manufacturing, service and sales by region } \\
\text { or country) } \\
\text { - Senior management years of prior experience in international business (e.g., } \\
\text { - } \quad \text { Mangth of service of senior management by countries or regions) } \\
\text { Manal competencies such as flexibility, openness, and cultural sensitivity }\end{array}$ \\
\hline - Headquarters international orientation & $\begin{array}{l}\text { - } \quad \text { Extent of ethnocentrism } \\
\text { - } \quad \text { Headquarters corporate culture maintained in foreign units } \\
\text { - } \quad \text { Proportion of non parent-country managers achieving headquarters positions, } \\
\text { application throughout the world }\end{array}$ \\
\hline
\end{tabular}




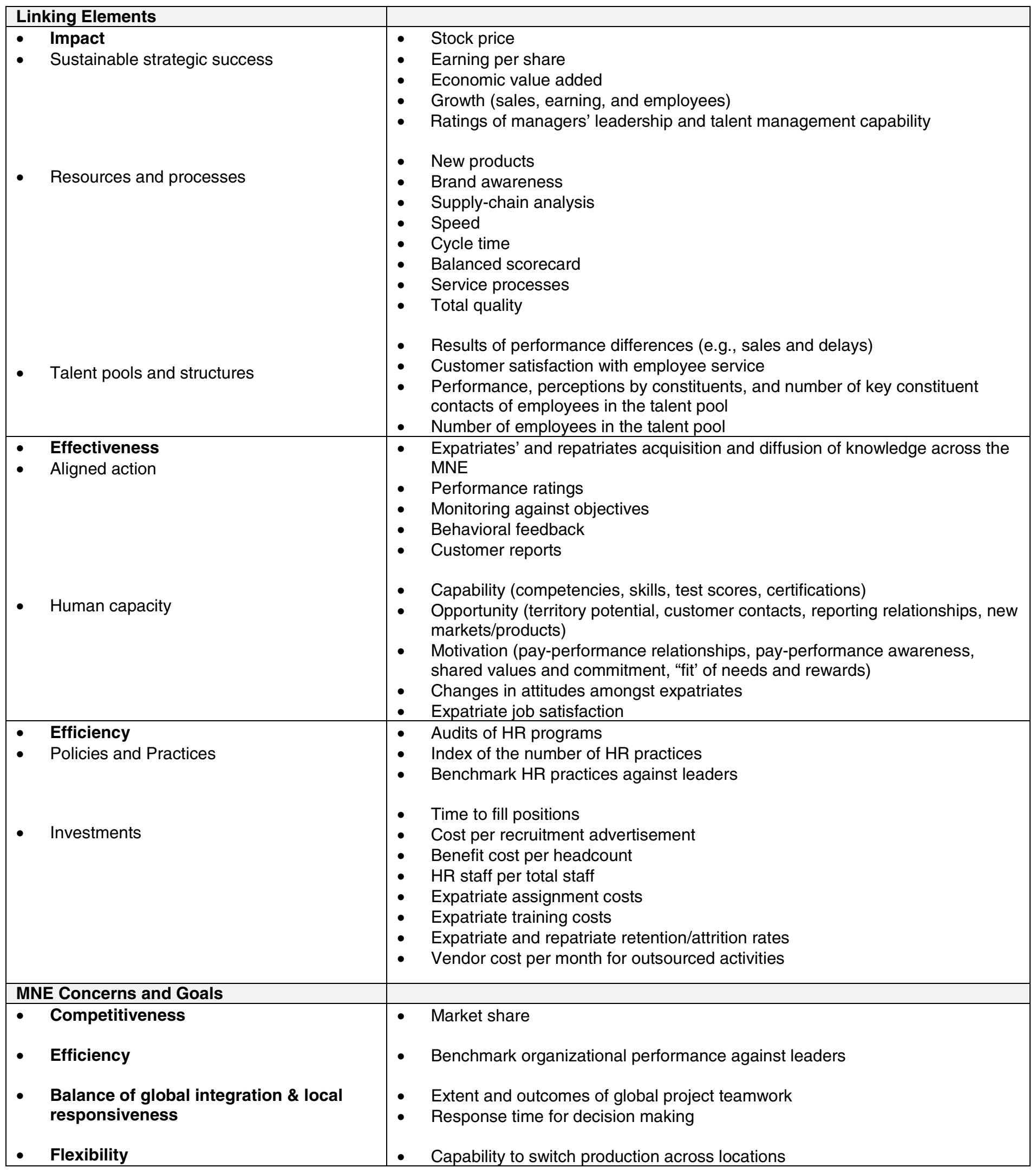

Adapted from: Boudreau, J. W., \& Ramstad, P.M. (2002a). Strategic l/O psychology and the role of utility analysis models. In W. Borman, D. Ilgen, \& R. Klimoski (eds.). Handbook of Psychology, (Vol. 12, "Industrial and Organizational Psychology", Chapter 9 , 193-221). New York: Wiley. 
The metrics shown in Table 1 are drawn from the wide array of possible approaches available for measuring global HR elements. We have selected measures that appear to have the greatest applicability to global HR elements. These include traditional evaluation of HR programs, utility analysis, financial efficiency measures of HR operations, benchmark surveys, HR activity and best practice indices, the balanced scorecard, and financial statement augmentation. This is not an exhaustive list of metrics. For a more detailed discussion of the growing array of alternative measurement tools available to organizational decision-makers, see Boudreau and Ramstad (2002a). Each approach may be useful for different purposes or circumstances; each has advantages and disadvantages.

Still, not every measurement approach is equally effective and appropriate for all situations. Recognizing that there is no "one best way," should not abdicate the obligation of HR scholars and leaders to build and use measures that effectively identify and enhance the key strategic talent decisions (Boudreau \& Ramstad, 2002b). Thus, Figure 1 and Table 1 provide not only a measurement taxonomy but, we hope, a point of departure for further enhancements to the logic underlying those measures, and their ability to articulate the key strategic connections. Only through such logical frameworks can we hope to guide the HR field toward improved measurement, not simply more measures.

\section{External Factors Influencing Global HR Metrics}

The first box in Figure 1 shows that there is a wide range of external factors that are important influences for global HR measurement. These include global/national/regional characteristics, industry characteristics and inter-organizational networks. Metrics for each of these factors are listed in Table 1.

With regard to global, national, or regional characteristics, a wide array of data pertaining to political, social, economic, and technological factors is available for MNEs to collect and analyze. Measurement of these external factors may be conducted in several ways, including benchmark surveys of national social conditions, such as surveys of employment practices, consumer preferences or social values. Government reports, non-governmental organization 
(NGO) reports and expert consultancy reports are major sources of political and economic intelligence. For example, the International Programme on the Elimination of Child Labour (IPEC), initiated by the International Labour Organization, is a 90-country alliance against child labour. A wide range of NGOs throughout the world work actively with IPEC, on activities including development and maintenance of statistical databases, sets of good management practices and manuals, guidelines and training materials. Another useful source of information is the A. T. Kearney/Foreign Policy Magazine Globalization Index, which attempts to measure the impact of globalization in 50 developed countries and key emerging markets worldwide. At a national or regional level, detailed information is essential for investment and performance decisions. For example, political risk analysis calculates the relative risk of elements such as political instability in a given country or region. Many MNEs utilize the services of external vendors who collate information from various sources and provide reports to the MNE on locations of interest. One of the MNE managers interviewed explained that her company uses an external vendor in conjunction with analysis provided by local management and a in-house risk assessment unit; this MNE has substantial numbers of employees in volatile locations.

Analysis of external factors has numerous implications for global HR management. For example, many MNEs provide salary premiums to expatriate employees on assignment in volatile locations; decisions about salary premiums rely upon accurate information about the location. Any MNE with plans for investment in Indonesia would need to evaluate the political risk associated with government instability, civil unrest, violence and threats of balkanization. Several MNEs, concerned about security and corruption, have abandoned Indonesian operations.

Industry characteristics may be measured using collection and analysis of information about factors such as key competitors and potential market share, supplier relationships, and customer perspectives. Industry analysis seeks to identify and understand the forces that influence the industry, such as the industry size and life cycle stage, factors influencing profitability, and changing players in the market (such as new entrants). For MNEs, industry 
analysis may need to include several levels: local (parent and host country), national, regional, and global industry levels. Industry surveys (for example, see Breaking New Ground, 2002) and competitor intelligence reports can be used to gather metrics such as the number and size of competitors, market maturity, projections for market growth or decline, relative pricing power and margins, and financial capital migration.

Inter-organizational networks may be complex relationship webs that are difficult to analyze and measure. Inter-organizational networks may be based upon personal relationships and trust; non-binding social contracts that may be, nevertheless, long-term, pervasive and strong in nature. Networks may include parent country managers and employees, host country managers and employees, host country governments, and investors. At the core of network management is an emphasis on talent that must recognize that knowledge, power, perceived trustworthiness, expertise, and social bonds are often person-specific rather than organizationspecific. Measures for networks include collection and analysis of HR data using methods such as questionnaires, interviews, and behavioral observation. There is a wide array of measures for knowledge that could be utilized in networks, relevant to the stock or flow of knowledge and to enabling processes related to the knowledge stock or flow (Boudreau, in press). Human and social capital data to be collected may include elements such as the level of trust between network members; quality, type, and quantity of relationships; and the importance of the network to each member organization. These metrics can be utilized as part of a global HR measurement framework.

For example, the International Network for Acid Prevention (INAP) brings together mining companies that wish to work collaboratively to reduce the impact of acid drainage, a significant environmental issue in the global mining industry. A key measure of networking for INAP is the maintenance of communication programs, including a website to facilitate knowledge sharing and networking activities on specific research projects. Outcomes credited to knowledge sharing in the network member organizations since the inception of INAP in 1998 include cost savings in millions of dollars. Referring back to Figure 1, this knowledge sharing 
may also be viewed as a global version of the linking element 'human capacity', because it utilizes employees' capability and opportunity for networking.

\section{Organizational Factors Influencing HR in MNEs}

Organizational factors refer to characteristics that are outside the HR area but may also have important influences on the MNE's global HR. Several methods may be used to measure these factors, and such measures can be developed to work within a global HR measurement framework.

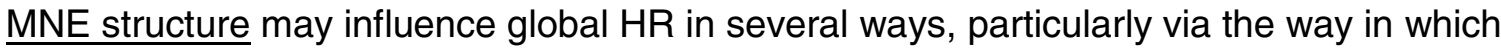
international operations are structured. For example, the level of decision-making in the MNE is an important consideration. Decision-making centralized at corporate headquarters may lead to quite different outcomes than decisions devolved to business units. The structural relationships between business units, including the extent of duplication or interdependence, may be important metrics. Intra-organizational networks may be subject to the same conditions as those networks external to the MNE. Again, important characteristics include the trust between network members; quality, type, and quantity of relationships; and communication and knowledge-sharing between network members. Metrics to assess the mechanisms of coordination may vary from highly formalized bureaucratic rules to cultural norms entrenched via socialization of employees to the organizational culture.

Models of organizational life cycle stages vary, but in general, the life cycle of a typical organization is argued to comprise four identifiable although possibly overlapping stages: birth, growth, maturity, and decline (and/or revival). Theory and research indicate that the organizational life cycle stage will be an important influence on HR practices (see, for example, Milliman, Von Glinow \& Nathan, 1991). Organizational life cycle stages may be measured by examining the organizational age, the age of key products/services, and projections for organizational growth or decline.

International entry mode, also known as the mode of foreign market service, has been examined extensively by researchers and practitioners. The evidence shows that green-field 
operations take longer than acquisitions or joint ventures to provide a financial return on investment. In the long term, surviving green-field operations outperform the other modes. Recent research suggests, however, that the opportunities for transfer of knowledge and learning in international joint ventures may provide an HR benefit beyond the outcomes achievable in green-fields or acquisitions. Examples of measures related to international entry mode include the extent of ownership or control in a joint venture, the percentage of joint venture managers who are expatriates, or the number of local versus expatriate employees.

MNE strategy may be measured in several ways. First, the approach to global markets may be explored by assessing the organization's capability for global integration or multidomestic differentiation. Are business decisions made with a local focus, or does the organization think globally for every decision? Second, the source of sustainable strategic success may be measured, for example, with metrics for dimensions of differentiation. Traditional dimensions of differentiation include price quality, innovation, speed, or customer responsiveness, but differentiation may also be encompass dimensions such as relationships with key constituents, or distribution and support functions (Boudreau et al., 2000).

Research has indicated that the extent of international business experience held by the managers, measured by their years of international experience and their level of cross-cultural competencies, will be positively correlated with MNE organizational success (Dowling et al., 1999). Examples of possible measures include the MNE's years of operation by region or country, the MNE's historical proportion of manufacturing, service and sales by region or country, and the length of service of senior management by countries or regions. Also, managerial competencies such as flexibility, openness, and cultural sensitivity will enhance global organizational performance (Dowling et al., 1999).

Further, the international orientation of MNE headquarters can have important implications for HR practices and global performance. In particular, ethnocentrism in the headquarters orientation and among senior management in MNEs, reinforced by dissemination of a strong headquarters culture, has been shown to be associated with poorer global 
organizational performance (Caligiuri \& Stroh, 1995). Examples of specific measures for headquarters' international orientation include the proportion of non-parent country nationals employed in headquarters management positions, or the number of regional innovations adopted by headquarters for application throughout the world. Typical of the situation in many MNEs, a global HR manager in a U.S. based MNE explained that the company is "U.S.-centric but it is well-recognized that expatriate assignments are an important and strategic part of career development". Some MNEs have moved to reinforce this in HR policies and practices. For example, Daimler Chrysler's strategy to develop global leaders at senior levels of the organization includes a '2x2x2' policy: A requirement that executives speak at least 2 languages, have worked in at least 2 of the 12 business units, and worked in at least 2 countries. Beyond this, 'soft skills' such as flexibility and openness are deemed to be essential for managers in a global context. These measures have interesting potential for applications to global leadership; perhaps items such as knowledge of languages, countries and business units, combined with a selection of 'soft skills' might form the basis of an index for global leadership, which could be customized for a particular MNE's requirements.

\section{Linking Elements}

The central part of Figure 1 shows the HC BRidge ${ }^{\mathrm{TM}}$ Model (Boudreau et al., 2000; Boudreau \& Ramstad, 2002a), which articulates the seven linking elements between contextual elements (external and organizational factors) and organizational performance outcomes. The seven linking elements are anchored by three points: impact, effectiveness, and efficiency. In the sections below we present illustrative metrics for these linking elements and analyze the advantages and disadvantages of the various approaches underlying the metrics.

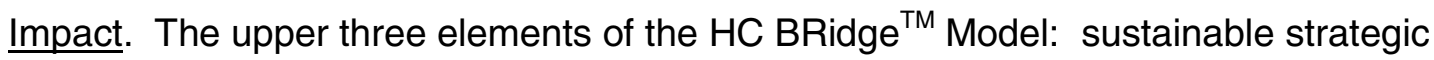
success, resources and processes, and talent pools and structures, comprise the impact section of the framework. Sustainable strategic success refers to competitive advantage as well as success factors such as corporate social responsibility. As shown in Table 1, sustainable strategic success can be measured by stock price, earning per share, economic value added, or 
growth figures, reported in financial statements. In addition, financial statements can be augmented with managers' reports of intangible assets. For example, the annual reports of many MNEs include at least some reporting of assets like the leadership and talent management capabilities of their managers. This emphasis on intangible assets should not only focus on management, but rather should include all employees, to develop a global 'line of sight', which encourages recognition of how individual employee behaviors relate to the strategic objectives of the organization (Boudreau \& Ramstad, 2002a).

While the financial statement augmentation approach may be appealing to financial analysts and perhaps to shareholders, there are significant limitations. First, there is no generally accepted method of reporting HR investments. Second, as the focus is usually on firm-level numbers, the difficulties of developing financial reporting for global HR programs may be substantial and this approach is likely to be limited in its ability to inform decisions about HR investments. Finally, this approach reveals little about the decision-making logic underlying the connections between HR investments and outcomes (Boudreau \& Ramstad, 2002a).

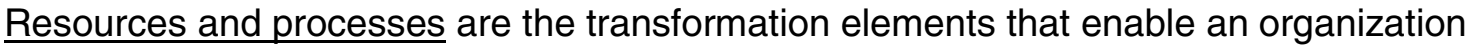
to add value (see Boudreau et al., in press, for more detail). Resources and processes can be measured by new products, brand awareness, supply-chain analysis, speed, cycle time, service processes, and total quality. The balanced scorecard can provide a tool to measure several of the linking elements, particularly with regard to impact elements such as resources and processes. This approach seeks to measure how the organization or the HR function meets objectives in four areas: customers, financial markets, internal processes, and learning and growth. Cargill uses an adaptation of the balanced scorecard throughout their operations worldwide. Boudreau and Ramstad (2002a) pointed out a vast array of global HR measures could be categorized into the balanced scorecard and a key benefit is that this approach is well known to many managers. There is also potential for flexibility, as software can allow users to "drill" or "cut" HR measures, to support their own analysis questions. A potential concern with 
the balanced scorecard, however, is that naïve users may misinterpret or mis-analyze the information (see Boudreau \& Ramstad, 2002b).

The term talent pools and structures, rather than jobs, is used to focus on contribution rather than administration (Boudreau \& Ramstad, 2002a, b). Measures of talent pools may include constituent relations or customer satisfaction with employee service. For example, the maintenance of positive relations with local government or other officials is an important process for many MNEs. The maintenance role may reside in no one individual but may encompass local managers and employees with personal contact, as well as those formally assigned the jobs of negotiating and maintaining such relationships. Measures may include the performance, perceptions by constituents, and number of key constituent contacts of these individuals. Even though there may be no particular "job" of government relations, these employees comprise a talent pool whose work collectively (and perhaps collaboratively) affects government and constituent relations.

Effectiveness. Effectiveness articulates how HR policies and practices connect to changes in the aligned actions of the talent pools. Aligned actions refer to the behaviors of those in the pivotal talent pools that make the largest difference in the elements of competitive success. For example, employees undertaking expatriation assignments or short-term forms of international work, acquire knowledge to be diffused throughout the MNE (Kamoche, 1996). Measures for these aligned actions include performance reviews, behavioral feedback, and customer reports. Boudreau et al. (in press) provide a detailed example of pre-sales engineers who were identified as key mediators in relationships between engineers in one country and salespeople in the U.S., even though their job description might not have included that aligned action. Recognition and measurement of the pivotal contribution of the pre-sales engineers had several implications, such as the strategic justification for HR investments (e.g., development and reward programs) to enhance their actions as 'diplomats' in their organization.

The Global Relocation Trends 2001 Survey (2002) found that, to save expatriation costs (particularly for U.S. expatriates), companies increasingly rely on short-term expatriate 
assignments, and use those assignments for development purposes. Measured in terms of cost savings and the amount of time of expatriate experience created, this appears sound. However, it is frequently the long-term expatriate that exhibits the aligned action of sharing their acquired knowledge and experience throughout the MNE, because longer-term expatriates not only have greater experience, but more status within the organization. Measures that specifically focus on this sort of information sharing behavior are required to clearly evaluate these tradeoffs.

Effectiveness also links changes in the key talent pools and structures to human capacity, including the impact of HR interventions on the capability, opportunity and motivation necessary to support aligned actions. Measures of capability may include competencies, such as test scores or skill acquisition. Measures of opportunity include territory potential or customer relationships. Motivation may be measured by attitude surveys, organizational values shared by employees, or perceived 'fit' between employee needs and their rewards. Potential measures for expatriate management might include changes in attitudes amongst expatriates, or expatriate job satisfaction.

The effectiveness area includes many elements of utility analysis measurement for HR programs, which requires assessments of variables such as knowledge, skills, performance, transformed into dollar values, and offset with estimated costs (Boudreau, 1991; Boudreau \& Ramstad, 2002a).

Utility analysis provides a wide array of possible approaches for estimating the possible returns on HR program investments. This approach to analysis provides useful logic and rigor. A criticism of utility analysis, however, is that the complexity and assumptions may reduce its credibility and usefulness in applications to global HR programs (Boudreau \& Ramstad, 2002a).

Efficiency. The resources expended in managing the impact and effectiveness of global $\mathrm{HR}$ are linked to the resulting HR policies and practices and investments via the efficiency anchor. Although many traditional HR measurement approaches concentrate primarily on efficiency measures, and these are useful, they must be embedded within the context of impact and effectiveness to avoid misinterpretation. For example, calculation of the cost of sending 
one expatriate on assignment must be considered in the organizational context. It has been estimated that a three-year expatriate assignment may cost US\$1 million or more, for an employee with a base salary of US\$75,000 to US\$100,000. Besides salary, additional direct costs may include housing allowance, cost of living allowances, education costs for children, home leave, shipping or storage of household goods, host country taxes, hardship premiums, danger pay, mobility allowances, and income taxes. Indirect costs may include changes to organizational and client relationships or changes for the expatriate's family members, such as disruption of a spouse's career. Further, 'expatriate failure' or premature return of an expatriate is a potentially high-costs problem, with direct costs such as replacement expenses and indirect costs such as loss of market share and damaged international relationships (Dowling et al., 1999). What are the alternatives? What value will be created through this assignment? How can expatriate assignments be best managed to achieve optimal outcomes, for individuals and the MNE?

Of course, a complete answer to these questions awaits further research, but we would propose that organizations that focus solely on expatriate costs may well overlook significant potential value, and either underutilize expatriates or deploy them improperly. For example, expatriate costs can likely be minimized by using the least expensive assignments, keeping them of short duration, and taking few risks of potential client or operations damage from poor performance. However, our framework suggests a more systematic view that would pose questions and attempt to measure connections between expatriate practices and the human capacity, aligned action, contribution to key talent pools linked to core processes and resources, and eventually to sustainable strategic success. For example, if organizations desire to build competitive success in environments where long-run relationships are key, and to develop leaders who have learned to operate in environments of high importance and significant potential, it may well be that expatriate assignments to 'hardship' (and thus expensive) locations, of longer duration, and specifically targeted to high-risk and high-return situations may be precisely the way to build the necessary human capacity for the future. This sort of logic is 
often hinted at, but seldom articulated in detail and even more rarely measured. We would suggest that a measurement framework such as that developed here might be a starting point to more complete analysis for decisions such as expatriation.

Measures for policies and practices have relied to some extent on HR activity and best practice indices, which measure the association between a collection of HR activities and changes in organizational outcomes such as profits and shareholder value creation (Becker \& Huselid, 1998; Cappelli \& Neumark, 2001). In terms of Figure 1, HR activity and best practice indices aim to link the policies and practices element with sustainable strategic success.

The best practice approach has been adopted in many MNEs. The focus has tended to be on specific HR activities, testing for relationships with specific actions and performance outcomes. For example, Caligiuri and Stroh's (1995) study of HR executives in 60 MNEs found the most successful companies had HR functions that performed better in three areas: developing global leadership through cross-cultural assignments, making HR a strategic partner in global business, and ensuring flexibility in all HR programs and processes. Their analysis suggested a positive relationship between the financial success of an organization and its HR performance in these three areas.

While HR activity and best practice indices may provide a more direct approach than utility analysis, Boudreau and Ramstad (2002a) pointed out that the research results for this approach should be treated with caution, as the causal mechanisms and direction of relationships may be unclear. This lack of clarity may lead to incorrect conclusions or actions.

Cargill administers an annual global HR survey of over 100 items related to HR policies and practices, to all employees. This measure enables correlation of global HR policies and practices with organizational performance, and identifies national differences in the policies and practices that predict organizational performance. Annual data collection and analysis in an organization of over 90,000 employees worldwide is a substantial undertaking. Their findings indicate that some $9 \%$ of the variance in global organizational performance is explained by HR programs. While this figure represents a small proportion of the total, this organization's efforts 
are noteworthy, given the complex linkages between HR practice and organizational performance. Referring again to Figure 1, we note that such measurements also provide a useful platform for the intermediate linking elements between HR practices and financial outcomes.

Measures for investments have relied to some extent on traditional evaluation of HR programs. While this has potential to provide a rich source of information on program effects, statistical results may not be easily translated into organizational goals. To utilize expatriation management as an example, many MNEs focus their HR efforts on the technical management of expatriates rather than encompassing strategic implications of expatriation. Hence, their expatriate HR measures focus on expatriate relocation costs such as housing, compensation and benefits, and family allowances. The most commonly used measures appear to be limited to the costs of expatriate selection, pre-departure training, and expatriate allowances and benefits-in sum, a restricted range of expatriate HR program elements are evaluated, if at all. Despite the substantial investment required for expatriation, surveys indicate a lack of measurement of expatriate and repatriate attrition rates. For example, the Global Relocation Trends 2001 Survey (2002) found that $49 \%$ of respondent organizations did not know the attrition rate of expatriates.

The HR investment metrics draw to some extent upon financial efficiency measures of HR operations. This measurement approach involves systems for calculating costs of HR programs and HR functions, with a variety of dollar- or time-based ratios for activities such as staffing, compensation, and expatriation. The focus of this category of measures is on calculating dollar-based indicators of HR operations and comparing these standardized indicators across organizations (Boudreau \& Ramstad, 2002a, b).

While several aspects of global HR have been measured in this way (e.g., expatriate selection and pre-departure training), reports indicate that relatively few organizations gather comprehensive efficiency measures for global HR activities. The matter of expatriate return-oninvestment (ROI) provides an example. According to the Global Relocation Trends 2001 
Survey (2002), "there is no universal understanding of the meaning of ROI, and there are few mechanisms in place for measuring it accurately" (p. 9). It is interesting to note that the Global Relocation Trends 2001 Survey (2002) found that MNEs that have partially or wholly outsourced their expatriation programs are better able to monitor costs, value, and performance of international assignments. The logic of our framework suggests enhanced measures of expatriation to enhance the identification and utilization of value that may exist there. We propose that, at the very least, expatriate $\mathrm{ROI}$ should involve some measures of repatriate retention and career development, knowledge sharing via global networking, or costs of expatriate and repatriate attrition. Although expatriation is probably the area of global HR where most would agree the greatest measurement has occurred, evidence suggests that expatriate measurement in many MNEs has been largely focused on the element of HR investments. Our framework provides both a general template and specific measures that might raise attention to the linking elements of effectiveness and impact of expatriation.

\section{Outcomes: MNE Concerns and Goals}

MNEs have numerous strategic concerns and goals, which may include the development and maintenance of transnational HR management systems, world-class HR management status, competitiveness, efficiency, balance of global integration and local responsiveness, and flexibility. These organizational outcomes are related to each of the preceding elements in our framework, and thus overlap to some extent. They may be viewed as global organizational outcomes of the other elements shown in Figure 1. For example, following Schuler et al. (1993) measures for competitiveness may include market share, and measures for efficiency include benchmark surveys of organizational performance against leaders. In addition, we note that either category may utilize measures we discussed earlier, related to industry or to MNE strategic dimensions of differentiation. The MNE's balance between global integration and local responsiveness may be measured by assessments of the extent and outcomes of global project teamwork, or by measurement of the response time for decision making. Finally, measures of the MNE's flexibility may include determination of the 
organizational capability to switch production across locations. These organizational outcomes may also be viewed as global outcomes of the linking elements shown in Figure 1.

\section{Summary and Conclusions}

Overall, the metrics we have discussed provide important contributions to the overall development and understanding of global HR measurement. In our review of global HR research and current practice, we found evidence that these measurement approaches are being applied to global HR in MNEs. However, even where an approach is being applied, there are evident constraints and challenges. To deal with the limitations of these measures, many MNEs use several of these measures in parallel. For example, Cargill uses several measures for their global HR measurement, including cost-benefit analysis, the balanced scorecard, and HR indices correlated with organizational performance. Indeed, we propose that the metrics are maximally useful when embedded into the decision model. MNEs that better understand the connection between human resources and strategic success on a global basis will win. To date, however, there appear to be relatively few examples of MNEs that understand and act to build this connection in tangible ways.

In this chapter, we have built upon the context of talentship, or decision-based HR, to articulate a framework for the measurement of global HR. We hope that the framework will help the practice of global HR metrics to move beyond the tendency to emphasize efficiency, the focus on expatriation measurement, the tantalizing correlations between global HR practices and financial outcomes that suggest the promise of better measurement, and the apparent situation where even organizations with relatively extensive measurement could benefit from a logical model that connects practices, talent and global strategic success. Our framework aims to reflect a strong and deep logical connection between resources, decisions, and organizational outcomes, to increase the impact, efficiency, and effectiveness of global HR. 


\section{End Notes}

${ }^{1}$ We define a multinational enterprise (MNE) as: any enterprise that carries out transactions in or between two sovereign entities, operating under a system of decision making that permits influence over resources and capabilities, where the transactions are subject to influence by factors exogenous to the home country environment of the enterprise (Sundaram \& Black (1992, p. 733).

${ }^{2} \mathrm{HC}$ BRidge ${ }^{\mathrm{TM}}$ is a trademark of the Boudreau-Ramstad Partnership. 


\section{References}

Becker, B., \& Huselid, M. (1998). High performance work systems and firm performance: A synthesis of research and managerial implications. Research in Personnel and Human Resource Management, 16, 53-101.

Becker, B., Huselid, M., \& Ulrich, D. (2001). The HR scorecard: Linking people, strategy and performance. Boston, MA: Harvard Business School Press.

Boudreau, J. W. (1991). Utility analysis for decisions in human resource management. In M. D. Dunnette \& L. M. Hough (Eds.), Handbook of industrial and organizational psychology (Vol. 2, pp. 621-745). Palo Alto, CA: Consulting Psychologists Press.

Boudreau, J. W. (1998). Strategic human resource management measures: Key linkages and the PeopleVANTAGE model. Journal of Human Resource Costing and Accounting, $\underline{3}$, 21-40.

Boudreau, J. W. (in press). Strategic knowledge measurement and management. In S. Jackson, M. Hitt \& A. DeNisi (Eds.), Managing knowledge for sustained competitive advantage: designing strategies for effective human resource management. San Francisco, CA: Jossey-Bass.

Boudreau, J. W., Dunford, B., \& Ramstad, P. M. (2000). The human capital "impact" on ebusiness: The case of Encyclopedia Britannica (CAHRS working paper 00-05). Ithaca, NY: Cornell University.

Boudreau, J. W., \& Ramstad, P. M. (1997). Measuring intellectual capital: Learning from financial history. Human Resource Management, 36, 343-356.

Boudreau, J. W. \& Ramstad, P. M. (2002a). Strategic I/O psychology and the role of utility analysis models. In W. Borman, D. Ilgen, \& R. Klimoski (eds.) Handbook of Psychology, (Vol. 12, "Industrial and Organizational Psychology", Chapter 9, 193-221). New York: Wiley.

Boudreau, J. W. \& Ramstad, P. M. (2002b). Strategic HRM measurement in the $21^{\text {st }}$ century: From justifying HR to strategic talent leadership (CAHRS working paper 02-15). Ithaca, NY: Cornell University.

Boudreau, J. W., Ramstad, P. M. \& Dowling, P. J. (in press). Global talentship: Toward a decision science connecting talent to global strategic success. In W. Mobley \& $P$. Dorfman (Eds.), Advances in Global Leadership (Vol. 3). Stamford, CT: JAI Press/Elsevier Science.

Breaking New Ground: The Final Report of the Mining, Minerals, and Sustainable Development Project, 2002. London: Earthscan Publications.

Caligiuri, P. M., \& Stroh, L. K. (1995). Multinational corporation management strategies and international human resources practices: Bringing IHRM to the bottom line. International Journal of Human Resource Management, $\underline{6}$, 494-507.

Cappelli, P., \& Neumark, D. (2001). Do "high-performance" work practices improve establishment-level outcomes? Industrial and Labor Relations Review, 54, 737-775.

De Cieri, H., \& Dowling, P. J. (1999). Strategic human resource management in multinational enterprises: Theoretical and empirical developments. In P. M. Wright, L. D. Dyer, J. W. Boudreau, \& G. T. Milkovich (Eds.), Research in Personnel and Human Resources Management: Strategic Human Resources Management in the Twenty-first Century (Supplement 4, pp. 305-327). Stamford, CT: JAI Press.

Dowling, P. J., Welch, D. E., \& Schuler, R. S. (1999). International HRM: Managing people in a multinational context ( $3^{\text {rd }}$ ed.). Cincinnati, OH: South-Western.

Global Relocation Trends 2001 Survey Report. (2002, February). Sponsored by GMAC Global Relocation Services, National Foreign Trade Council (NFTC), and SHRM Global Forum.

Kamoche, K. (1996). The integration-differentiation puzzle: A resource capability perspective in international human resource management. International Journal of Human Resource Management, $\underline{7}, 230-44$. 
Lepak, D. P., \& Snell, S. (1999). The human resource architecture: Towards a theory of human capital allocation and development. Academy of Management Journal, 24, 3148.

Milliman, J., Von Glinow, M. A., \& Nathan, M. (1991). Organizational life cycles and strategic international human resource management in multinational companies: Implications for congruence theory. Academy of Management Review, 16, 318-339.

Murphy, T. E., \& Zandvakili, S. (2000). Data- and metrics-driven approach to human resource practices: Using customers, employees and financial metrics. Human Resource Management, 39, 93-105.

Schuler, R. S., Dowling, P. J., \& De Cieri, H. (1993). An integrative framework of strategic international human resource management. Journal of Management, 19, 419-459.

Stroh, L. K., \& Caligiuri, P. M. (1998). Strategic HR: A new source for competitive advantage in the global arena. International Journal of Human Resource Management, $\underline{9}$ (1), 1-17.

Sundaram, A. K., \& Black, J. S. (1992). The environment and internal organization of multinational enterprises. Academy of Management Review, 17, 729-757.

\section{Recommended References for Global HR Metrics}

Boudreau, J. W., Dunford, B., \& Ramstad, P. M. (2000). The human capital "impact" on ebusiness: The case of Encyclopedia Britannica (CAHRS working paper 00-05). Ithaca, NY: Cornell University.

Boudreau, J. W. \& Ramstad, P.M. (2002). Strategic I/O psychology and the role of utility analysis models. In W. Borman, D. Ilgen, \& R. Klimoski (eds.). Handbook of Psychology, (Vol. 12, "Industrial and Organizational Psychology", Chapter 9, 193-221). New York: Wiley.

De Cieri, H., \& Dowling, P. J. (1999). Strategic human resource management in multinational enterprises: Theoretical and empirical developments. In P. M. Wright, L. D. Dyer, J. W. Boudreau, \& G. T. Milkovich (Eds.), Research in personnel and human resources management: Strategic human resources management in the twenty-first century (Supplement 4, pp. 305-327). Stamford, CT: JAI Press.

Dowling, P. J., Welch, D. E., \& Schuler, R. S. (1999). International HRM: Managing people in a multinational context ( $3^{\text {rd }}$ ed.). Cincinnati, OH: South-Western.

Florkowski, G. W., \& Schuler, R. S. (1994). Auditing human resource management in the global environment. The International Journal of Human Resource Management, $\underline{5}$, 827-851. 
Helen De Cieri, Ph.D., is an Associate Professor of human resource management in the Department of Management, Monash University (Australia). Her academic experience includes appointments in Australia, China, Hong Kong, Malaysia and the USA. Her teaching, research, and consulting interests are concerned with global and strategic HR management. She has published over 60 journal articles and monographs. Helen is the past Editor of the Asia Pacific Journal of Human Resources (1996-2002). She received her Ph.D. from the University of Tasmania.

John W. Boudreau, Ph.D., Professor of human resource studies at Cornell University is recognized worldwide for breakthrough research on the bridge between superior human capital, talent and sustainable competitive advantage. His research has received the Academy of Management's Organizational Behavior New Concept and Human Resource Scholarly Contribution awards. Dr. Boudreau consults and conducts executive development with companies worldwide that seek to maximize their employees' effectiveness by quantifying the strategic bottom-line impact of superior people and human capital strategies, including Boeing, Bristol-Myers Squibb, Citigroup, GE, IBM, JP Morgan Chase, Novartis, Schering-Plough, Shell International, Sun Microsystems, Transamerica, the United Nations, Verizon, and WilliamsSonoma. Professor Boudreau was an architect and the first Visiting Director of Sun Microsystems' unique Research and Development Laboratory for Human Capital. Professor Boudreau is a Fellow of the National Academy of Human Resources.

Dr. Boudreau has published more than 40 books and articles. In addition to HR metrics, Dr. Boudreau's large-scale research studies and highly focused qualitative research have addressed decision-based HR, executive mobility, HR information systems and organizational staffing and development. His research findings have been published in Management Science, Academy of Management Executive, Journal of Applied Psychology, Organizational Behavior and Human Decision Processes, Personnel Psychology, Asia-Pacific Human Resource Management, Human Resource Management, Journal of Vocational Behavior, Human Relations, Industrial Relations, Journal of Human Resources Costing and Accounting, and Personnel Administrator. He co-authored a best-selling textbook on human resource management that reached its eight edition and was translated into Chinese, Czech, Spanish and others.

Features on his work have appeared in The Wall Street Journal, Fortune, Business Week, Training, and Human Resources Management. The winner of the General Mills Award for teaching innovations, Dr. Boudreau also founded the Central Europe Human Resource Education Initiative, which links American HR professionals and academic researchers with faculty and students in the Czech and Slovak Republics. A strong proponent of corporate/academic partnerships, Dr. Boudreau has directed the Center for Advanced Human Resource Studies (CAHRS), which partners executives from America's top corporations with university researchers and students to explore leading-edge HR issues. This Cornell University "think tank" has generated groundbreaking insights and practical solutions for the human resource challenges that affect most organizations today.

Dr. Boudreau is a member of the board of advisors for Brassring.com, a technology information and career portal. He chaired the Academic Advisory Board of the California Strategic HR Partnership, a silicon-valley HR executive consortium, and served on the boards of advisors for the Saratoga Institute, a leading global source of human capital benchmarking and performance measures. He has also been elected to the executive committees of the Human Resources Division of the Academy of Management and the Society for Industrial and Organizational Psychology. Dr. Boudreau holds an undergraduate degree in business from New Mexico State University, and a Masters degree in Management and Ph.D. in industrial relations from Purdue University's Krannert School of Management. 